\title{
Variations in sulphate aerosols concentration during winter monsoon season for two consecutive years using a general circulation model
}

\author{
S. VERMA \\ Centre for Excellence in Climatology, ABirla Institute of Technology Mesra, \\ Extension Centre Jaipur, Rajasthan, India. \\ Corresponding author; e-mail: verma.sunita@bitmesra.ac.in \\ O. BOUCHER \\ CNRS, Laboratoire de Météorologie Dynamique, Ecole Normale Supérieure, Université de Paris, France. \\ H. C. UPADHYAYA and O. P. SHARMA \\ Centre for Atmospheric Sciences, Indian Institute of Technology Delhi, New Delhi, India.
}

Received March 13, 2012; accepted October 29, 2012

\begin{abstract}
RESUMEN
Durante las investigaciones de campo del Experimento del Océano Índico (INDOEX, por sus siglas en inglés), se llevaron a cabo mediciones exhaustivas de la composición química y el contenido de aerosoles de la atmósfera para estudiar el transporte de largo alcance de la contaminación atmosférica desde el sur y el sureste de Asia hacia el Océano Índico, durante la estación seca del monzón en 1998 y 1999. Este trabajo analiza las variaciones temporales y espaciales de los aerosoles y su forzamiento durante la estación invernal (de enero a marzo) en la primera fase de campo (FFP, por sus siglas en inglés) y la fase intensiva de campo (IFP, por sus siglas en inglés) del INDOEX, las cuales se llevaron a cabo en 1998 y 1999, respectivamente. Se utilizó un modelo interactivo de química y aerosoles (LMDZ.3.3) para investigar las variaciones espaciales en la distribución de aerosoles troposféricos de sulfato durante 1998 y 1999. Los resultados de este modelo muestran un incremento considerable en las concentraciones de aerosoles de sulfato, el forzamiento radiativo y la profundidad óptica en el subcontinente indio y zonas oceánicas circundantes entre la FFP y la IFP del INDOEX. También se simuló un incremento importante en el transporte de aerosoles de sulfato desde la zona continental hacia el Océano Índico durante el monzón de invierno de 1999. El forzamiento radiativo medio en el INDOEX-FFP de 1998 fue de $-1.2 \mathrm{Wm}^{-2}$ y aumentó a $-1.85 \mathrm{Wm}^{-2}$ durante el INDOEX-IFP de 1999. Los resultados del modelo arrojan una profundidad óptica media de aerosoles de sulfato de 0.08 y 0.14 sobre el subcontinente indio en 1998 y 1999, respectivamente. Estos resultados sugieren que las actividades antropogénicas en dicha región pueden afectar de manera significativa al entorno oceánico circundante.
\end{abstract}

\footnotetext{
ABSTRACT

During the field cruises of the Indian Ocean Experiment (INDOEX) extensive measurements on the atmospheric chemical and aerosol composition are undertaken to study the long-range transport of air pollution from south and southeast Asia towards the Indian Ocean during the dry monsoon season in 1998 and 1999. The present paper discusses the temporal and spatial variations in aerosols and aerosol forcing during the winter monsoon season (January-March) for INDOEX first field phase (FFP) in 1998 and INDOEX intensive field phase (IFP) in 1999. An interactive chemistry/aerosol model (LMDZ.3.3) is used to investigate the variation in the spatial distribution of tropospheric sulphate aerosols during 1998 and 1999. The model results depict major enhancement in the sulphate aerosol concentrations, radiative forcing (RF) and optical depth over the Indian subcontinent and adjoining marine areas between INDOEX-FFP and IFP. A significant increase in transport of sulphate aerosols from the continents to the Indian Ocean region has also been simulated during
} 
the winter monsoon in 1999. The mean RF over INDOEX-FFP in 1998 is found to be $-1.2 \mathrm{Wm}^{-2}$ while it increased to $-1.85 \mathrm{Wm}^{-2}$ during INDOEX-IFP in 1999. Model results reveal a mean sulphate aerosol optical depth (AOD) of 0.08 and 0.14 over Indian subcontinent during 1998 and 1999, respectively. The model results suggest that elevated AOD downwind of source regions in India can significantly affect the regional air quality and adjoining marine environments.

Keywords: Aerosols, emissions, radiative forcing, GCM, transport.

\section{Introduction}

The recognition of widespread pollution (south Asian brown haze) during the Indian Ocean Experiment (INDOEX) has led to serious concern and speculation about the causes. This recognition has triggered a large number of observations, analyses and modeling studies to identify and understand the aerosols origin, spatial distribution, transport and role in climate change over the Indian Ocean (Satheesh et al., 1999, 2002; Rajeev et al., 2000; Satheesh and Ramanathan, 2000; Ramanathan et al., 2001, 2002). Aerosol transport and its impact on radiative forcing were estimated over the tropical Indian Ocean during INDOEX (Krishnamurty et al., 1998; Podgorny et al., 2000; Rajeev et al., 2001). General circulation model (GCM) simulations over south Asia during the INDOEX period with the high resolution regional emissions information (Reddy et al., 2004; Verma et al., 2008, 2012) indicate the likely contribution of emissions from regions outside India to aerosol loading over the Indian subcontinent and adjoining oceans.

Yet to give a better estimate on increasing aerosol concentration, and its impact on the surrounding climate and general circulations, it is important to study their temporal and spatial distributions at different scales. The INDOEX campaign began with ship and land based observations in 1995-1997 and was intensified during a first field phase (FFP) during 1998 (Mitra, 1999) and culminated with the intensive field phase (IFP) during 1999, which included a large variety of platforms and measurements (Ramanathan et al., 2001). INDOEX measurements in 1998 and 1999 have indicated that aerosols play a significant role in climate change over India. It is therefore required to assess the climate forcing caused by sulphate aerosol and infer its possible influences over India and the Indian Ocean. Such estimates can be made with help of the general circulation models.

The INDOEX results have shown a pollution haze over the Arabian Sea and the Indian Ocean as a result of transport of pollutants from the Indian subcontinent (Ramanathan et al., 2001). Elevated aerosols loading was observed in a remote marine environment over the Arabian Sea during INDOEX 1999. The chemical transport models have been used widely for atmospheric simulations over southern Asia during the INDOEX period (Rajeev et al., 2000; Rasch et al., 2001; Podgorny and Ramanathan, 2001; Reddy et al., 2004; Verma et al., 2008, 2012), and have shown a predominance of sulphate in the south Asian region. Most of the INDOEX studies emphasize the underestimated impact of aerosols on climate (Jayaraman et al., 2001; Ramanathan et al., 2002; UNEP, 2002). One of the important findings of the INDOEX is the evidence of a strong enhancement in aerosols concentration during the observation period 1998-1999.

The present study aims to simulate and investigate the regional distribution of sulphate aerosol concentration during the winter monsoon season (January-March) for the INDOEX-FFP in 1998 and INDOEX-IFP in 1999 using a general circulation model (GCM). The extent of sulphate aerosol incursion and its relative influence is investigated by comparing the tropospheric sulfate concentration and spatial patterns over the Indian subcontinent and the Indian Ocean during the aforementioned INDOEX period. The connection between the winter circulation pattern and the dynamics of formation of sulphate aerosols concentration is also illustrated, which can improve understanding on the role of sulphate aerosols on global climate. For this purpose an interactive chemistry module developed at IIT Delhi combined with LMDZ (a variable grid GCM of Dynamic Meterological Lab, Paris) is used to simulate sulphur chemistry during INDOEX (Verma et al., 2007).

\section{Methodology}

\subsection{Model description}

The present simulations of sulphate aerosol distribution were carried out with the general circulation 
model LMDZT with interactive sulphur chemistry of the Laboratoire de Météorologie Dynamique (Verma et al., 2007). The sulphur chemistry is calculated directly within the LMDZT and allows for the complex interaction between chemistry and climate to consider the role of sulphate aerosols on the climate system, in comparison to other chemical transport models (CTMs) which employ analyzed meteorology or observations to derive the CTM. The chemistry includes emission, transport, gas and aqueous phase. There are 16 prognostic tracers in the model. Due to strong interaction between the gas and aerosol phases, the newly developed model (interactive gas phase) is fully coupled with an aerosol module that provides aerosol mass and number distribution. The aerosol module presented in the model is based on the Community Multiscale Air Qulaity (CMAQ) model of Binkowski and Shankar (1995), which is also part of Model-3 (Binkowski and Rosell, 2003) of the U.S. Environmental Protection Agency (EPA). In addition to number concentrations, the oxidant fields of $\mathrm{OH}, \mathrm{HO}_{2}, \mathrm{CO}, \mathrm{O}_{3}, \mathrm{H}_{2} \mathrm{O}_{2}, \mathrm{NH}_{3}$ and $\mathrm{NOx}$ are also predicted within the GCM. The model includes a set of parameterizations for convection, radiative transfer, planetary boundary layer (PBL) and ground hydrology with no vegetation. For a complete description of the processes one may refer to Sadourny and Laval (1984), Le Treut et al. (1994), Li (1999), and Lott (1999). The mass flux simulated by Tiedtke (1984) is used for convective transport of gases and aerosols. The three optical properties of aerosols: mass extinction efficiency, single scattering albedo, and asymmetry factor are obtained from Mie theory by using a size distribution and refractive indices of sulphate aerosols (Verma et al., 2006). The shortwave radiative processes within the LMDZT are accounted by dividing the shortwave spectrum into two intervals of 0.25-0.68 $\mu \mathrm{m}$ and 0.68-4 $\mu \mathrm{m}$ wavebands. More description on the model can be found in Verma et al. (2007).

\subsection{Emissions}

Sulphur emissions of the Global Emission Inventory Activity (GEIA) are used. Global sulphur emissions in the GEIA database include emissions from fossil fuels combustion and industrial processes. The biomass burning sulphur emissions are taken from Pham et al. (1996) (Table I). The global annual anthropogenic $\mathrm{SO}_{2}$ emissions from fossil fuel combustion and industrial activities are $66.31 \mathrm{Tg} \mathrm{S} \mathrm{yr}^{-1}$. A fixed 5\% of sulphur from combustion sources is assumed to be emitted as sulphate mass. We are not considering volcanic source of $\mathrm{SO}_{2}$ emissions. The anthropogenic source of $\mathrm{H}_{2} \mathrm{~S}$ is $2.82 \mathrm{Tg} \mathrm{S} \mathrm{yr}^{-1}$ (Watts, 2000). For oceanic emissions, dimethylsulfide (DMS) concentration of Kettle et al. (1999) and the sea to air parameterization of Liss and Merlivat (1986) are used.

Table I. Global annual sulphur emissions in the model $\mathrm{Tg} \mathrm{S} \mathrm{yr}{ }^{-1}$

\begin{tabular}{|c|c|c|c|c|}
\hline Sources & $\mathrm{SO}_{2}$ & $\mathrm{H}_{2} \mathrm{~S}$ & DMS & Total \\
\hline Biosphere: & & 0.41 & 0.29 & 0.60 \\
\hline $\begin{array}{l}\text { (1) Vegetation } \\
\text { (2) Soils }\end{array}$ & & 0.02 & 0.02 & 0.04 \\
\hline Biomass burning: & 3.99 & & & 3.99 \\
\hline Ocean: & & & 19.00 & 19.00 \\
\hline Man-made: & 66.31 & 2.82 & & 69.13 \\
\hline Total & 74.11 & 3.27 & 19.31 & 94.03 \\
\hline
\end{tabular}

Note: $5 \%$ of man-made $\mathrm{SO}_{2}$ is emitted directly as sulphate.

\section{Simulations}

For the present study, two simulations (December to March season) were performed for INDOEX-FFP 1998 (EXP01) and for INDOEX-IFP 1999 (EXP02) using LMDZ GCM. The changes in local aerosol emissions between the two years were also taken into account while conducting both experiments. The present simulations were performed using a resolution of $3.75^{\circ}$ longitude, $2.5^{\circ}$ latitude and 19 vertical levels with a time step of $30 \mathrm{~min}$. The model initial state was estimated from analyses of the European Centre for Medium-Range Weather Forecasts (ECMWF) performed on December 20th, 1997 (EXP01) and December 20th, 1998 (EXP02) with appropriate boundary conditions. The first 10 days of simulations were needed for stabilization of the model parameters, and results discussed in the following sections were obtained from the period January-March for both simulations.

\section{Results and discussions}

\subsection{Model evaluation}

To validate the model simulation, we compared (Fig. 1) simulated sulphate aerosol optical depth (AOD) with measurements (Satheesh and Ramanathan, 2000) at Kaashidhoo (KCO, $4.965^{\circ} \mathrm{N}$, 


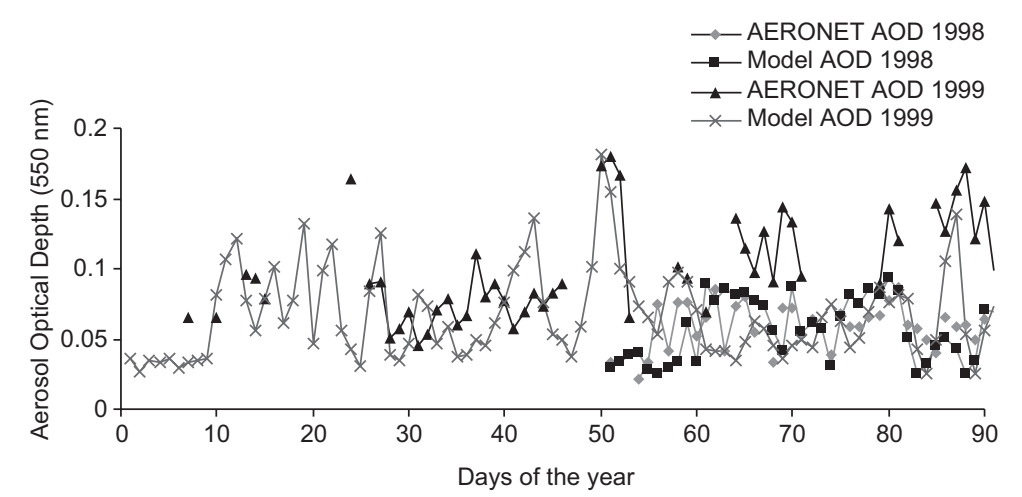

Fig. 1. Modeled and observed sulphate aerosol optical depth (AOD) for the period January to March 1998 and 1999 at Kaashidhoo $\left(73.46^{\circ} \mathrm{E}, 4.96^{\circ} \mathrm{N}\right)$. Note: The AERONET observed AOD is derived from all aerosol constituents using a linear relation; sulphate is responsible for $29 \%$ of the total AOD (Satheesh and Ramanathan, 2000).

73.466 ${ }^{\circ}$ E) during INDOEX-IFP 1998 and FFP 1999. Predicted sulphate AOD matches well with the measured values, indicating the model's capability to predict the vertically integrated column aerosol properties with acceptable precision. Thus the LMDZ model describes well the sulphate aerosols plumes over the INDOEX domain; however, the magnitudes of these plumes can be underestimated at a point location, as is also evident from earlier studies using the model version described here (Verma et al., 2006, 2007, 2012). The results (Fig. 1) are also supported by the comparison of optical depth over the north Indian Ocean during the winter of 1998 and 1999 (Ramanathan et al., 2001; Rajeev et al., 2000).

\subsection{Spatial distribution}

The LMDZ model has the capability of reproducing the spatial distribution of aerosols over Asia and capturing the major features of AOD spatial distribution, as is evident from Verma et al., 2006, 2007. Figures 2 and 3 show $\mathrm{SO}_{2}$ and sulphate aerosols concentrations simulated by LMDZ over the INDOEX region, respectively. The model captures the average spatial patterns of $\mathrm{SO}_{2}$ and sulphate aerosols concentration (Figs. 2, 3) very precisely as observed over the INDOEX domain. Simulated $\mathrm{SO}_{2}$ concentration shows high concentration values (1-3 $\mathrm{g} \mathrm{m}^{-3}$ ) over the Indian subcontinent, with a marginal transport into the oceanic regimes in 1998, which increased to 2-6 $\mu \mathrm{g} \mathrm{m}^{-3}$ during 1999. Like $\mathrm{SO}_{2}$, the simulated sulphate mass concentra- tion strikes out a high concentration over Indian subcontinent including Southeast Asia and China. Unlike $\mathrm{SO}_{2}$, a strong transport of sulphate aerosols into surrounding oceanic regions (Ramanathan et al., 2001) has been evident in EXP01 and EXP02 simulations. The average sulphate concentration has been enhanced over Indian continents with a value of $1.5-3$ to $3-6 \mu \mathrm{g} \mathrm{m}^{-3}$ (Fig. 3) over Indian subcontinent with a significant transport to the oceanic region in 1999.

There are numerous sources of pollution over the regions of India, in particular over the Indo Gangetic Plains (IGP), creating an intense haze over most of the continent. All of these aerosol clouds can cross the Indian continent and often yield high concentrations over the Indian Ocean, as can be inferred from Figure 3. The model is capable of showing the responses of the sulphate aerosol distribution pattern to the changes in wind circulation during both years of study. There is a strong plume of surface sulphate concentrations (Fig 3b) over the Arabian Sea extending to the Bay of Bengal and the northern Indian Ocean. The extension of the plume from continental to ocean areas suggests the transport of aerosols by northwesterly winds from Arabia and northeasterly winds from Indian subcontinent to Arabian Sea, whereas over the Bay of Bengal transport is mainly from Southeast Asia, including Indonesia and Sumatra (Fig. 3a, b). Sulphate shows high values at $850 \mathrm{mb}$ (Fig. 3b) over south and east India $\left(4-8 \mu \mathrm{g} \mathrm{m}^{-3}\right)$ during IFP. Observations reported by Rasch et al. (2001) are also in agreement with 
(a)

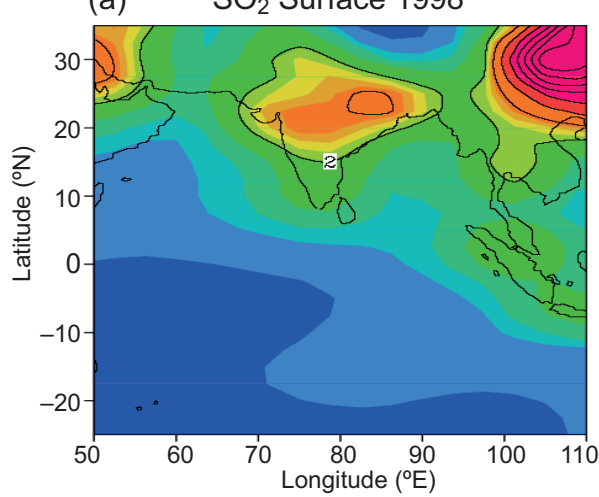

(c)

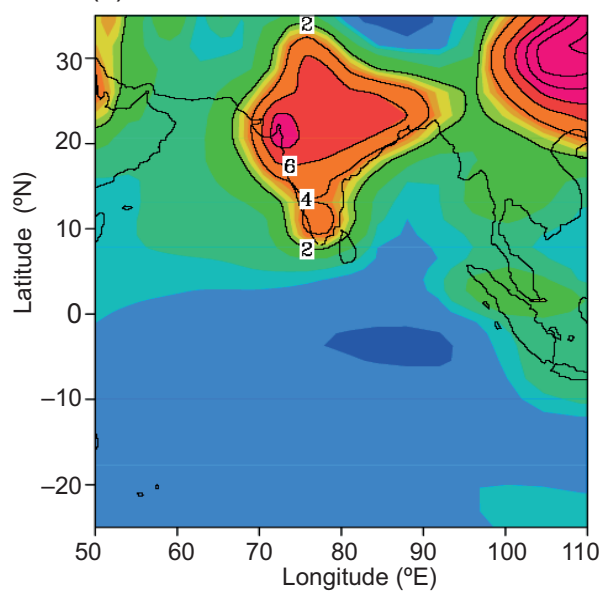

(b)

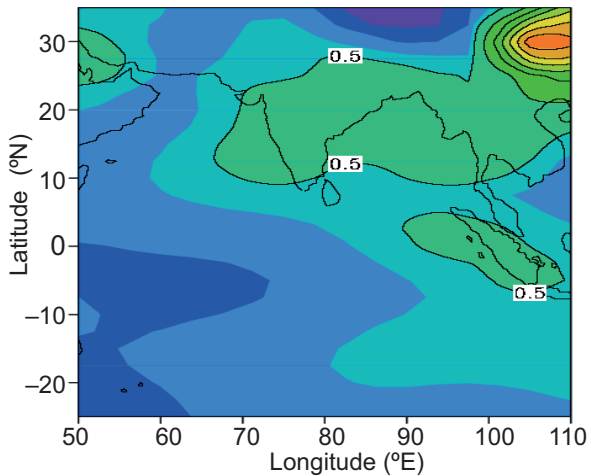

(d)

$\mathrm{SO}_{2} 850 \mathrm{hPa} 1999$

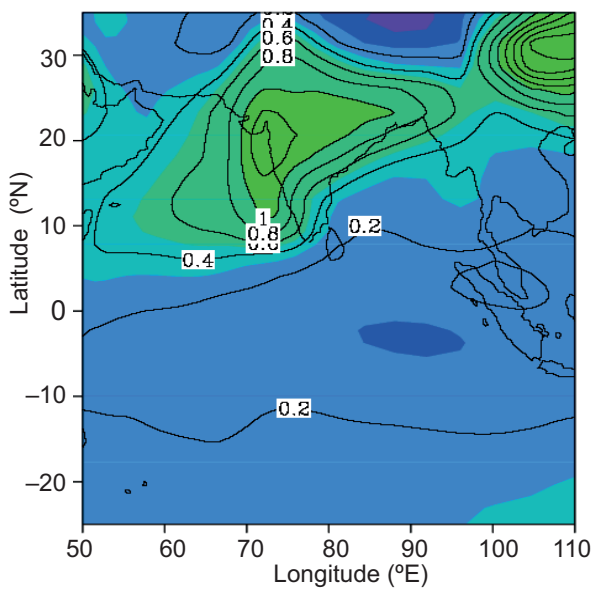

Fig. 2. $\mathrm{SO}_{2}$ average distribution from January to March 1998 (upper) and 1999 (lower) for the INDOEX domain. (a, c) Surface concentration $\left(\mu \mathrm{g} / \mathrm{m}^{3}\right)$. (b, d) Model level $5(\sim 850 \mathrm{hPa})$.

the modeled average sulphate concentrations for the entire INDOEX region during IFP and are consistent with earlier model studies.

Elevated AOD from 0.1 to 0.15 is recorded over KCO adjoining the Arabian Sea. The LMDZ simulated radiative forcing (RF) and AOD in Exp01 and Exp02 are compared in Figure 4a, b, respectively. The average background sulphate RF is found to be -0.5 to $-1.75 \mathrm{Wm}^{-2}$ and AOD is found to be 0.1 to 0.14. During 1999, the simulated RF and AOD (Fig. 4) derived from sulphate aerosols suggest an overall increase in sulphate loading over the Indian subcontinent, the Arabian Sea and the Bay of Bengal. The largest values of RF and AOD lie over southeast China, where the anthropogenic source of sulphur is very intense. An area of large AOD (0.08-0.14) is observed (Fig. 4a) extending from southeast China and covering India. Higher AOD values are also noted over the southeastern part of India with a maximum of 0.14 . It is most likely that high levels of
AOD over southeastern subcontinents are the result of photochemical processes as they are near to urban areas that are sources of sulphur. A high AOD in the northern Bay of Bengal (0.04-0.1) is also observed, which extends deep into the Arabian Sea $\left(15^{\circ} \mathrm{S}\right)$. The southeastern part of the Arabian Sea (0.08-0.12) is strongly influenced by emissions from India. AOD over the Arabian Sea (0.12) is found to be more than three times higher compared with the remote Indian Ocean (0.04), south of the Intertropical Convergence Zone (ITCZ). Excessive AOD values (about 25\% higher) in the plumes downwind of urban sites is much more pronounced during 1999 than in 1998 (Fig. 4b) due to unstable atmospheric conditions and higher sources of sulphate precursors (Fig. 2c). The spatial extent of mean sulphate AOD over INDOEX in 1998 is 0.08 , two times higher than in $1999(0.14)$. The mean RF over INDOEX-FFP 1998 is found to be $-1.2 \mathrm{Wm}^{-2}$ while it increased to $-1.85 \mathrm{Wm}^{-2}$ during INDOEX-IFP 1999. 
(a)

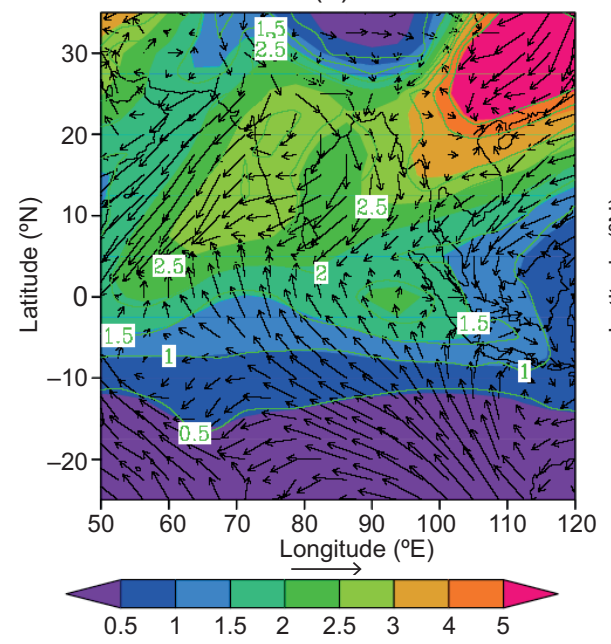

(c)

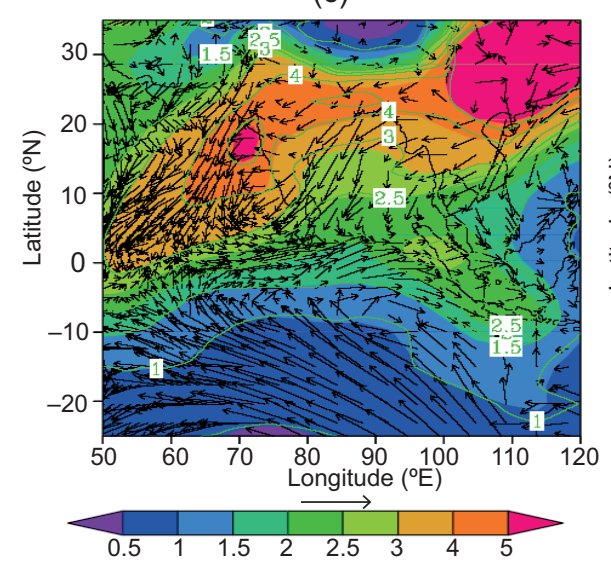

(b)

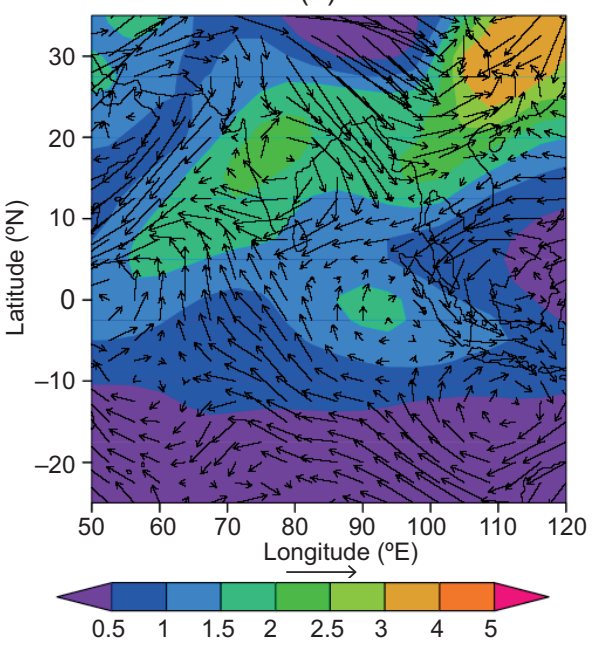

(d)

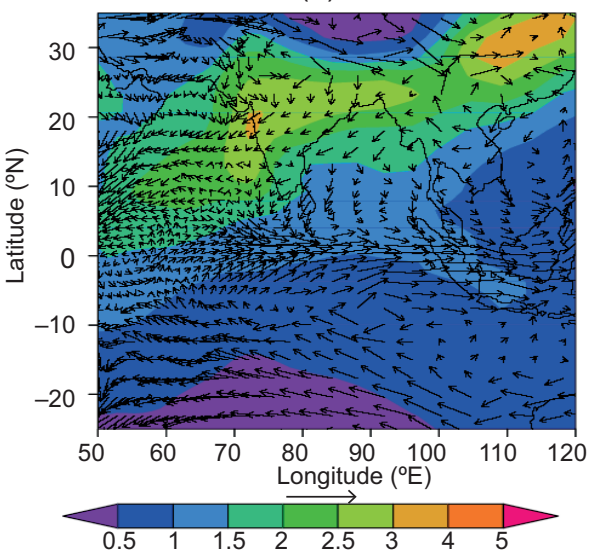

Fig. 3. Sulphate average distribution from January to March 1998 (upper) and 1999 (lower) for the INDOEX domain. (a, c) Surface concentration $\left(\mu \mathrm{g} / \mathrm{m}^{3}\right)$. (b, d) Model level $5(\sim 850 \mathrm{hPa})$.

\section{Summary and conclusions}

In this study, the LMDZ model is used to simulate sulphate aerosol distributions during INDOEX-IFP 1998 and INDOEX-FFP 1999. The model simulations were first validated in comparison with INDOEX observations. The model reproduces the sulphate aerosols concentration over INDOEX region within acceptable agreement. At Kaashidhoo, the model simulated AOD compares well with the observations.

In general, the spatial pattern of aerosols concentrations in the LMDZ simulations shows a higher AOD in EXP02. The difference in the AOD distributions between the two experiments illustrates a high AOD during EXP02 primarily because of the intense urban sulphur source and stronger wind intensities. The results clearly show that the aerosol loading over the continent in India has increased significantly in 1999 . The model precisely simulates the variations in sulphate aerosols during 1998 and 1999, and predicts a large difference in sulphate aerosol mass concentration, RF and optical depth between the two years. The mean RF over INDOEX-FFP 1998 is found to be $-1.2 \mathrm{Wm}^{-2}$ while it increased to $-1.85 \mathrm{Wm}^{-2}$ during INDOEX-IFP 1999. The spatial extent of mean sulphate aerosol optical depth (AOD) over the Indian subcontinent in 1999 is 0.14 , which is twice as large than in 1998 (0.08). The model results document the fact that increasing anthropogenic activities in the Indian subcontinent can significantly affect its adjoining marine environments. 
(a)
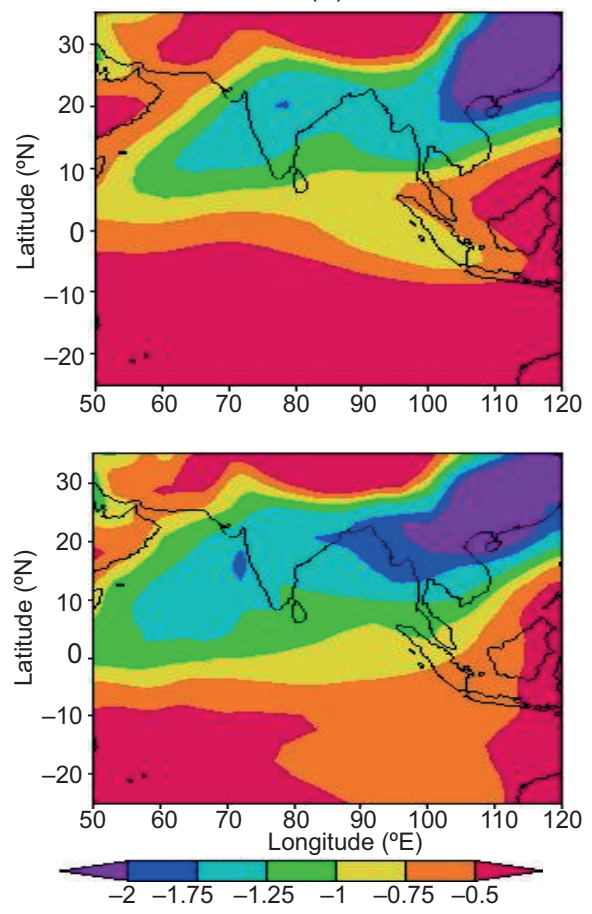

(b)
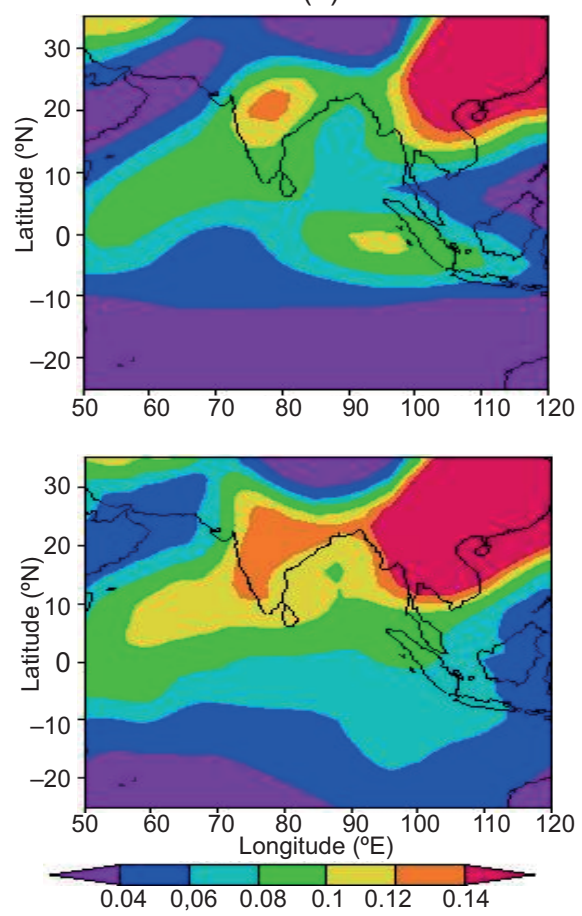

Fig. 4. Sulphate (a, c) radiative forcing and (b, d) aerosol optical depth average from January to March 1998 (upper) and 1999 (lower) for the INDOEX domain.

\section{Acknowledgements}

Computing resources at BIT were supported through a grant from SERB, Department of Science and Technology (DST), Government of India, under project (SR/S4/AS:39/2009). The authors would like to acknowledge the INDOEX program for observational datasets. This work was initiated with the encouragement of professor O. P. Sharma, when the first author was at the Indian Institute of Technology Delhi with the financial support of the Indo-French Centre for Promotion of Advanced Research (IFCPAR/CEFIPRA) under project 1911-2. This study is part of a collaborative project also supported by the Indo-French Centre for the Promotion of Advanced Research (IFCPAR). The first author acknowledges the support of professor Purnendu Ghosh, Executive Director of the Birla Institute of Scientific Research (BISR) to carry forward this research work.

\section{References}

Binkowski F. S. and U. Shankar, 1995. The regional particulate matter model: Part 1, model description and preliminary results. J. Geophys. Res. 100, 26191-26209.

Binkowski F. S. and S. J. Roselle, 2003. Models-3 Community Multiscale Air Quality (CMAQ) model aerosol component 1. Model description. J. Geophys. Res. 108, doi:10.1029/2001JD001409.

Jayaraman A., S. K. Satheesh, A. P. Mitra and V. Ramanathan, 2001. Latitude gradient in aerosol properties across the Inter Tropical Convergence Zone: Results from the joint Indo-US study onboard Sagar Kanya. Curr. Sci. India 80, 128-137.

Kettle A. J., M. O. Andreae, D. Amouroux, T. W. Andreae, T. S. Bates, H. Berresheim, H. Bingemer, R. Boniforti, M. A. J. Curran, G. R. DiTullio, G. Helas, G. B. Jones, M. D. Keller, R. P. Kiene, C. Leck, M. Levasseur, G. Malin, M. Maspero, P. Matrai, A. R. McTaggart, N. Mihalopoulos, B. C. Nguyen, A. Novo, J. P. Putaud, S. Rapsomanikis, G. Roberts, G. Schebeske, S. Sharma, R. Simó, R. Staubes, S. Turner and G. Uher, 1999. A global database of sea surface dimethylsulfide (DMS) measurements and a procedure to predict sea surface DMS as a function of latitude, longitude, and month. Global Biogeochem. Cy. 13, 399-444, doi:10.1029/1999GB900004.

Krishnamurti T. N., B. Jha, J. Prospero, A. Jayaraman and V. Ramanathan, 1998. Aerosol and pollutant transport and their impact on radiative forcing over the tropical Indian Ocean during the January-February 1996 pre-INDOEX cruise. Tellus B 50, 521-542.

Le Treut H., Z. X. Li and M. Forichon, 1994. Sensitivity study of LMD GCM to green house forcing associated 
with two different cloud water parametarizations. $J$. Climate 7, 1827-1841.

Li Z. X., 1999. Ensemble atmospheric GCM simulation of climate interannual variability from 1979 to 1994. J. Climate 12, 986-1001.

Liss P. S. and L. Merlivat, 1986. Air-sea gas exchange rates: Introduction and synthesis. In: The role of airsea exchange in geochemical cycling (P. Buat-Monard, Ed.). D. Reidel, Dordrecht, Holland, pp. 113-127.

Lott F., 1999. Alleviation of stationary bias in a GCM through a mountain drag parameterization scheme and a simple representation of mountain lift forces. Mon. Weather Rev. 127, 788- 801.

Mitchell J. F. B. and T. C. Johns, 1997. On modification of global warming by sulphate aerosols. J. Climate 10, 245-267.

Mitra A. P., 1999. INDOEX (India): Introductory note. Curr. Sci. India 76, 886-889.

Pham M., J. F. Muller, G. Brasseur, C. Granier and G. Mégie, 1996. A 3-D model study of the global sulfur cycle: Contributions of anthropogenic and biogenic sources. Atmos. Environ. 30, 1815-1822.

Podgorny I. A, W. Conant, V. Ramanathan and S. K. Satheesh, 2000. Aerosol modulation of atmospheric and surface solar heating over the tropical Indian Ocean. Tellus B 52, 947-958.

Podgorny I. A. and V. Ramanathan, 2001. A modeling study of the direct effect of aerosols over the tropical Indian Ocean. J. Geophys. Res. 106, 24097-24105.

Rajeev K., V. Ramanathan and J. Maywerk, 2000. Regional aerosol distribution and its long range transport over the Indian Ocean. J. Geophys. Res. 105, 2029-2043.

Rajeev K. and V. Ramanathan, 2001. Direct observations of clear-sky aerosol radiative forcing from space during the Indian Ocean Experiment. J. Geophys. Res. 106, 17221-17235.

Ramanathan V., P. J. Crutzen, J. Lelieveld, A. P. Mitra, D. Althausen, J. Anderson, M. O. Andreae, W. Cantrell, G. R. Cass, C. E. Chung, A. D. Clarke, J. A. Coakley, W.D. Collins, W.C. Conant, F. Dulac, J. Heintzenberg, A. J. Heymsfield, B. Holben, S. Howell, J. Hudson, A. Jayaraman, J. T. Kiehl, T. N. Krishnamurti, D. Lubin, G. McFarquhar, T. Novakov, J. A. Ogren, I. A. Podgorny, K. Prather, K. Priestley, J. M. Prospero, P. K. Quinn, K. Rajeev, P. Rasch, S. Rupert, R. Sadourny, S. K. Satheesh, G.E. Shaw, P. Sheridan and F. P. J. Valero, 2001. The Indian Ocean Experiment: An integrated analysis of the climate forcing and effects of the great Indo-Asian haze. J. Geophys. Res. 106, 28371-28398.

Ramanathan V., P. J. Crutzen, A. P. Mitra and D. Sikka, 2002. The Indian Ocean Experiment and the Asian brown cloud. Curr. Sci. India 83, 947-955.
Rasch P. J., W. D. Collins and B. E. Eaton, 2001. Understanding the Indian Ocean Experiment (INDOEX) aerosol distributions with an aerosol assimilation. $J$. Geophys. Res. 106, 7337-7355.

Reddy M. S., O. Boucher, C. Venkataraman, S. Verma, J. F. León, N. Bellouin and M. Pham, 2004. General circulation model estimates of aerosol transport and radiative forcing during the Indian Ocean Experiment. J. Geophys. Res. 109, D16205, doi:10.1029/2004JD004557.

Sadourny R. and K. Laval, 1984. January and July performances of LMD general circulation model. New perspectives in climate modelling. In: New perspectives in climate modeling. Developments in Atmospheric Science (A. Berger and C. Nicolis, Eds.). Elsevier, pp. 173-198.

Satheesh S. K., V. Ramanathan, X. Li-Jones, J. M. Lobert, I. A. Podgorny, J. M. Prospero, B. N. Holben and N. G. Loeb, 1999. A model for the natural and anthropogenic aerosols over the tropical Indian Ocean derived from Indian Ocean Experiment data. J. Geophys. Res. 104, 27421-27440.

Satheesh S. K. and V. Ramanathan, 2000. Large differences in tropical aerosol forcing at the top of the atmosphere and Earth's surface. Nature 405, 60-63, doi:10.1038/35011039.

Satheesh S. K., V. Ramanathan, B. N. Holben, K. Krishna Moorthy, N. G. Loeb, H. Maring, J. M. Prospero and D. Savoi, 2002. Chemical, microphysical, and radiative effects of Indian Ocean aerosols. J. Geophys. Res. 107, 4725, doi:10.1029/2002JD002463.

Tiedtke M., 1984. The effects of penetrative cumulus convection on the large scale flow in a general circulation model. Beitr. Atmos. Phys. 57, 216-239.

UNEP, 2002. The Asian brown cloud: Climate and other environmental impacts. Assessment report UNEP/ DEWA/RS.02-3. United Nations Environment Programme, Center for Clouds, Chemistry and Climate, available at: www.rrcap.unep.org/abc/impactstudy/.

Verma S., O. Boucher, H. C. Upadhyaya and O. P. Sharma, 2006. Sulfate aerosols forcing: An estimate using a three-dimensional interactive chemistry scheme. Atmos. Environ. 40, 7953-7962.

Verma, S., O. Boucher, M. S. Reddy, H. C. Upadhyaya, P. Le Van, F. S. Binkowski and O. P. Sharma, 2007. Modeling and analysis of aerosol processes in an interactive chemistry general circulation model. J. Geophys. Res. 112, D03207, doi:10.1029/2005JD006077.

Verma S., C. Venkataraman and O. Boucher, 2008. Origin of surface and columnar INDOEX aerosols using source- and region-tagged emissions transport in a general circulation model, J. Geophys. Res. 113, D24211, doi:10.1029/2007JD009538, 2008.

Verma S., O. Boucher, M. S. Reddy, H. C. Upadhyaya, P. 
Levan, F. Binkowski and O. P. Sharma, 2012. Tropospheric distribution of sulphate aerosol number and mass concentrations for INDOEX-IFP and its transport over Indian Ocean: a GCM study. Atmos. Chem. Phys. 12, 6185-6196, doi:10.5194/acp-12-6185-2012.
Watts S. F., 2000. The mass budgets of carbonyl sulfide, dimethyl sulfide, carbon disulfide and hydrogen sulfide. Atmos. Environ. 34, 761-779. 